\title{
Knowledge Structures and Components of Rural Resilience in the 2010s: Conceptual Development and Implications
}

\author{
GoWoon Kim ${ }^{1}$, Wanmo Kang ${ }^{2}$ and Junga Lee ${ }^{3, * \mathbb{D}}$ \\ 1 O-Jeong Resilience Institute (OJERI), Korea University, Seoul 02841, Korea; agneskim@korea.ac.kr \\ 2 Department of Forest Environment and Systems, College of Science and Technology, Kookmin University, \\ 77 Jeongneung-ro, Seongbuk-gu, Seoul 02707, Korea; kangwm@kookmin.ac.kr \\ 3 Life and Environment Research Institute, Sanghuh College of Life Sciences, Konkuk University, \\ Seoul 05029, Korea \\ * Correspondence: archjung@konkuk.ac.kr
}

Received: 17 October 2020; Accepted: 19 November 2020; Published: 23 November 2020

\begin{abstract}
Resilience is being widely adopted as a comprehensive analytical framework for understanding sustainability dynamics, despite the conceptual challenges in developing proxies and indicators for researchers and policy makers. In our study, we observed how the concept of resilience undergoes continued extension within the rural resilience literature. We comprehensively reviewed rural resilience literature using keyword co-occurrence network $(\mathrm{KCN})$ analysis and a systematic review of shortlisted papers. We conducted the $\mathrm{KCN}$ analysis for 1186 papers to characterize the state of the rural resilience literature, and systematically reviewed 36 shortlisted papers to further examine how rural resilience analysis and its assessment tools are helping understand the complexity and interdependence of rural social-ecological systems, over three three-year periods from 2010 to 2018. The results show that the knowledge structure built by the high frequency of co-occurrence keywords remains similar over the three-year periods, including climate change, resilience, vulnerability, adaptation, and management, whereas the components of knowledge have greatly expanded, indicating an increased understanding of rural system dynamics. Through the systematic review, we found that developing resilience assessment tools is often designed as a process to strengthen adaptive capacity at the household or community level in response to global processes of climate change and economic globalization. Furthermore, community resilience is found to be an interesting knowledge component that has characterized rural resilience literature in the 2010s. Based on our study, we summarized conceptual characteristics of rural resilience and discussed the challenges and implications for researchers and policy makers.
\end{abstract}

Keywords: adaptation; keyword co-occurrence network analysis; rural resilience; resilience assessment; systematic review; vulnerability

\section{Introduction}

Resilience has emerged as a useful concept to enhance the understanding of complex interrelationships between ecological and social systems across scales in the late 20th century [1-3]. Since then, the resilience concept has drawn and built upon a wide range of fields and disciplines, leading to different notions and realms of resilience. Recent scientific scholarship shows the increasing use of the concept to analyze the sustainability dynamics of rural areas and rural communities [4]. The interdisciplinary analysis of rural resilience encompasses facets of human ecology, ecological economics, rural sociology, and environmental studies [5], and discusses the internal and external factors affecting rural sustainability dynamics, such as the impacts of global climate change on natural resource-dependent communities that practice rain-fed agriculture $[6,7]$. 
Having a specific geographic and thematic boundary, such as rural resilience and urban resilience, may help to contextualize resilience and develop proxies and indicators that are more relevant to local interrelationships and processes [8]. For instance, it is now widely recognized that rural social-ecological systems provide the majority of the global food supply and natural resources, yet are being impacted by economic disparity, political instability, population decline, climate change, and the resulting degradation of natural ecosystems and biodiversity loss [9-11]. This understanding shows much improved systems conceiving insights that challenge dominant views on rural sustainability, wherein rural sustainability is merely seen as interrelated with sustainable natural resource management practices and rural livelihoods [12-15].

Nevertheless, the increasing interest in the resilience concept and its application to natural resources management and rural resilience have also encountered challenges: the concept has extensively remained academic and theoretical, resulting in inadequate empirical evidence for field-tested work and little contribution to natural resources management [2]. In order to address these challenges and to develop evidence-based approaches and tools for rural resilience, there is a need to understand the current application of the resilience concept in rural thematic fields and how this is facilitating the creation of relevant knowledge and assessment criteria. There is substantive scientific literature on comprehensive reviews of the development of urban resilience [16-18], yet few studies have undertaken similar comprehensive reviews of the development of rural resilience across disciplines [19].

A comprehensive review of the scientific literature on rural resilience can perform two important functions: (1) identify the multidisciplinary areas where rural resilience is being used and/or influencing the characterization of resilience concept and relevant knowledge; and (2) examine how rural resilience analysis and its quantitative and qualitative approaches are helping understand the dynamics of rural systems across scales and addresses the current conceptual challenges of resilience.

To this end, we employ a two-step approach proposed by Radhakrishnan et al. [20] to conduct a comprehensive review of rural resilience studies: a key-word co-occurrence network (KCN) analysis and a systematic review of selected papers containing field-tested evidence for the application of rural resilience. Using this approach, we aimed to achieve the following: (a) to characterize the state of rural resilience studies by identifying knowledge components, structures, and networks of rural resilience studies; (b) to observe evidence-based tools or indicators of rural resilience that are proposed in the relevant literature; (c) discuss the significance and limitations of rural resilience studies toward addressing the current academic challenges of the resilience concept as well as toward enhancing rural sustainability dynamics.

\section{Materials and Methods}

\subsection{Frameworks and Definitions of Resilience}

The resilience assessment of a social-ecological system is inherently dependent on the pre-analytic understanding of the system and the conceptualization of the resilience framework applied for the system's analysis [21]. This has led to various approaches for assessing resilience, such as engineering resilience, ecological resilience, social-ecological resilience, social resilience, development resilience, socioeconomic resilience, community resilience, and psychological resilience [21].

Different approaches may use narrow definitions of resilience, but the review of the studies shows that the broadly accepted definitions of resilience can be summarized in four ways: (1) the amount of disturbance a system can absorb and still retain the same controls on domain functions and structure; (2) the degree to which a system is capable of self-organization; (3) the ability of a system to build the capacity for learning and adaptation while embracing changes [9,22]; and (4), predominantly in the psychological sense, the ability to maintain a certain level of well-being [21].

In addition to the aforementioned notion of resilience, i.e., a quality of a complex adaptive system, it is also described as a normative concept and often situated along a spectrum of "good" and "bad," occasionally resulting in the oppositional relationship between the terms resilience and 
vulnerability [23]. On this account, resilience is often discussed as an ultimate goal to be achieved in many planning theories and practices, influencing policy-making and planning to aim to enhance adaptive capacity and reduce the vulnerability of the given system [23].

Vulnerability and adaptation are strongly related with the resilience concept and have been an important discussion topic for researchers to clarify the precise nature of their relationships [24,25]. It would be an interesting question to examine how the terms vulnerability, adaptation, and resilience are situated in rural resilience literature, which will be addressed later in this research.

\subsection{Methodological Approach}

The comprehensive review of the rural resilience literature was conducted in two steps (Figure 1): first, a KCN analysis that provided visual and quantitative insight on knowledge structure and evolution [26,27]; and second, a systematic literature review to observe the characteristics of evidence-based resilience assessments or measurements, which help to deepen the understanding of the subject and discern its gaps [28].

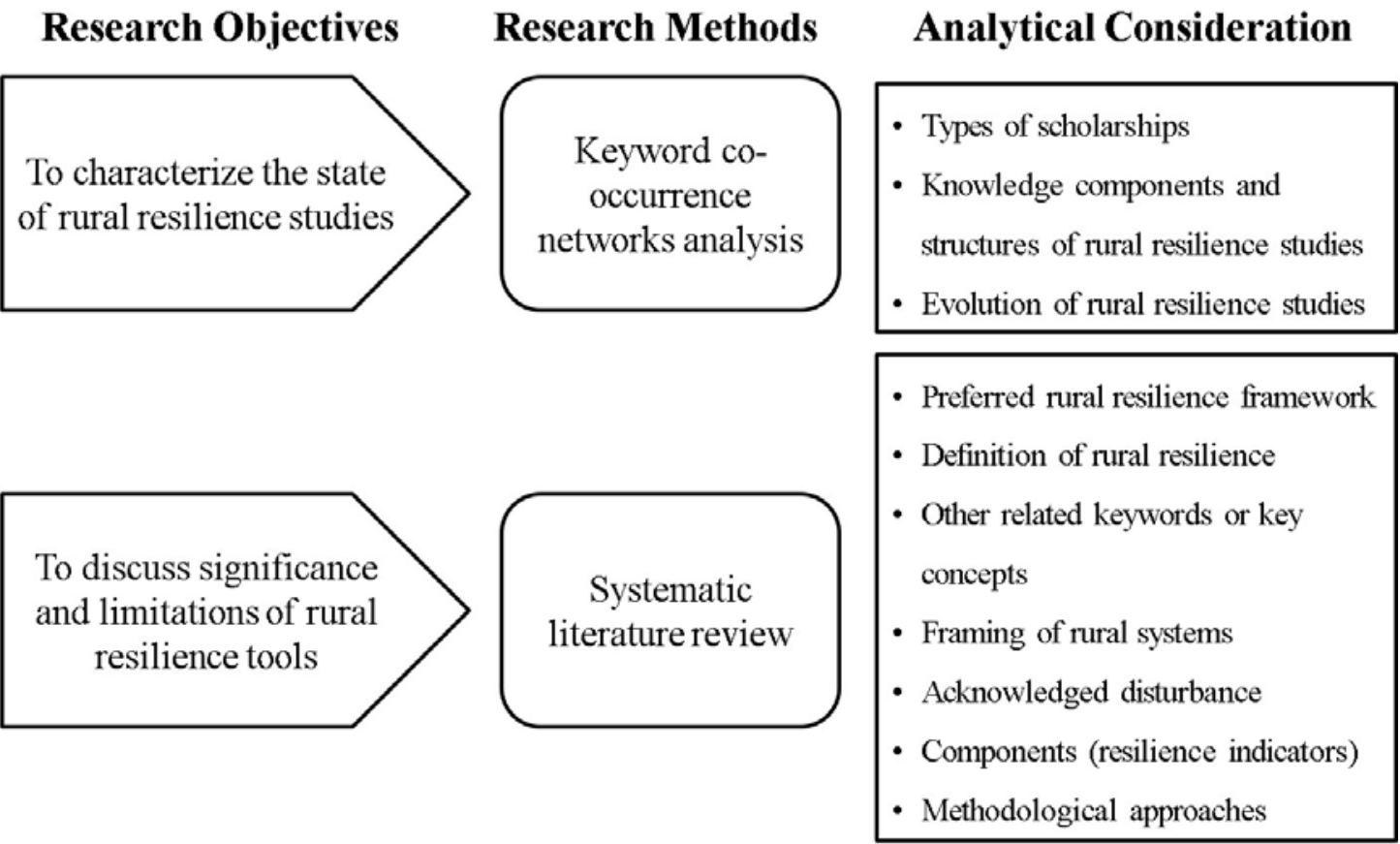

Figure 1. Methodological flowchart.

The preliminary investigation, prior to the $\mathrm{KCN}$ analysis, showed that studies related to rural resilience emerged during the 1980s and sharply increased in the 2000s; there were 18 papers published during the period 1990-1999, 165 papers during the period 2000-2009, and 1441 papers during the period 2010-2018. Hence, scientific papers published between 2010 and 2018 and related to "rural" and "resilience" were collected from the Science Citation Index Expanded (SCI-EXPANDED) and Social Sciences Citation Index (SSCI) databases available through the Web of Science. The collected papers were organized in three three-year periods to analyze the evolution of knowledge components, structure, and research trends [20]: 2010-2012, 2013-2015, and 2016-2018.

\subsubsection{Metrics of Keyword Co-Occurrence Networks}

The KCNs were constructed as undirected, unweighted networks using R (3.5.2) software [29]. Since our focus is on the co-evolving pattern of connectedness (i.e., the overall position of keywords), we applied unweighted network analysis rather than weighted network for calculating betweenness centrality (see also [30]) and degree centrality. In our approach, the degree represents the total number 
of links incident on the node, and betweenness centrality indicates the number of times the keywords (i.e., nodes) are included in the shortest paths between all pairs of nodes in the keyword network [20]. Although unweighted networks contain less information than their weighted counterparts [20], they can be analyzed with more ease and efficiency than the latter [31].

We investigated the characterization of nodes (keywords), links (the co-occurrence of the words), and network structure in the rural resilience literature, mainly based on the degree and betweenness centrality measures with the $\mathrm{R}$ package of igraph [32]. In addition to the visual exploration of keyword co-occurrence patterns with degree values, we conducted statistical tests to check the fitting of power-law distributions using the Kolmogorov-Smirnov (KS) test in the R packages of igraph and poweRlaw [33]. To detect the community structure of frequent keywords (i.e., at least five occurrences) within each time window, we performed cluster analysis based on edge betweenness in the R package of igraph [34].

\subsubsection{Systematic Review of Selected Papers}

The subsequent systematic review of the literature was conducted based on the results of the $\mathrm{KCN}$ analysis. We devised a five-stage approach drawing upon methods used for reviews of studies in biological conservation [35] and adaptive co-management [36], which include the following: question formulation, search protocol, screening of results, analysis, and synthesis. Details of each stage are explained in Appendix A.

\section{Results}

\subsection{Keyword Co-Occurrence Networks Analysis}

The number of keywords and links for the three time periods were 689 and 2265 for 2010-2012, 1413 and 5094 for 2013-2015, and 2264 and 8054 for 2016-2018, respectively (Table 1). The increase in nodes, i.e., the introduction of new keywords across each time window represents the expansion of knowledge structure in the rural resilience literature. The general increasing trend of the average degree represents the introduction of new keywords that did not emerge in the earlier literature.

Table 1. Summary of topological characteristics of keyword co-occurrence network (KCN) for rural resilience literature for three time periods: 2010-2012, 2013-2015, and 2016-2018.

\begin{tabular}{cccc}
\hline & $\mathbf{2 0 1 0 - 2 0 1 2}$ & $\mathbf{2 0 1 3 - 2 0 1 5}$ & $\mathbf{2 0 1 6 - 2 0 1 8}$ \\
\hline Number of articles & 170 & 375 & 641 \\
Nodes & 689 & 1413 & 2264 \\
Links & 2265 & 5094 & 8054 \\
Average degree $<\mathrm{k}>$ & 6.57 & 7.21 & 7.11 \\
Clusters & 5 & 13 & 16 \\
\hline
\end{tabular}

Figure 2 shows the degree distribution of the $\mathrm{KCN}$ for the three time periods with the $\mathrm{y}$ axis representing the complementary cumulative probability values and the $x$ axis representing the degree values. All co-occurrence networks of three time periods display a scale-free degree distribution, exemplified by the presence of power-laws $P(k) \sim k^{-\gamma}$ [37]. Scale-free networks are topologically dominated by a few highly connected hubs [37], which, in our study, agree well with the result related to top keywords by degree and betweenness (Table 3): a few highly co-occurring keywords such as "resilience" and "climate change" have relatively high values in betweenness playing a role in creating a new highly connected hubs. 

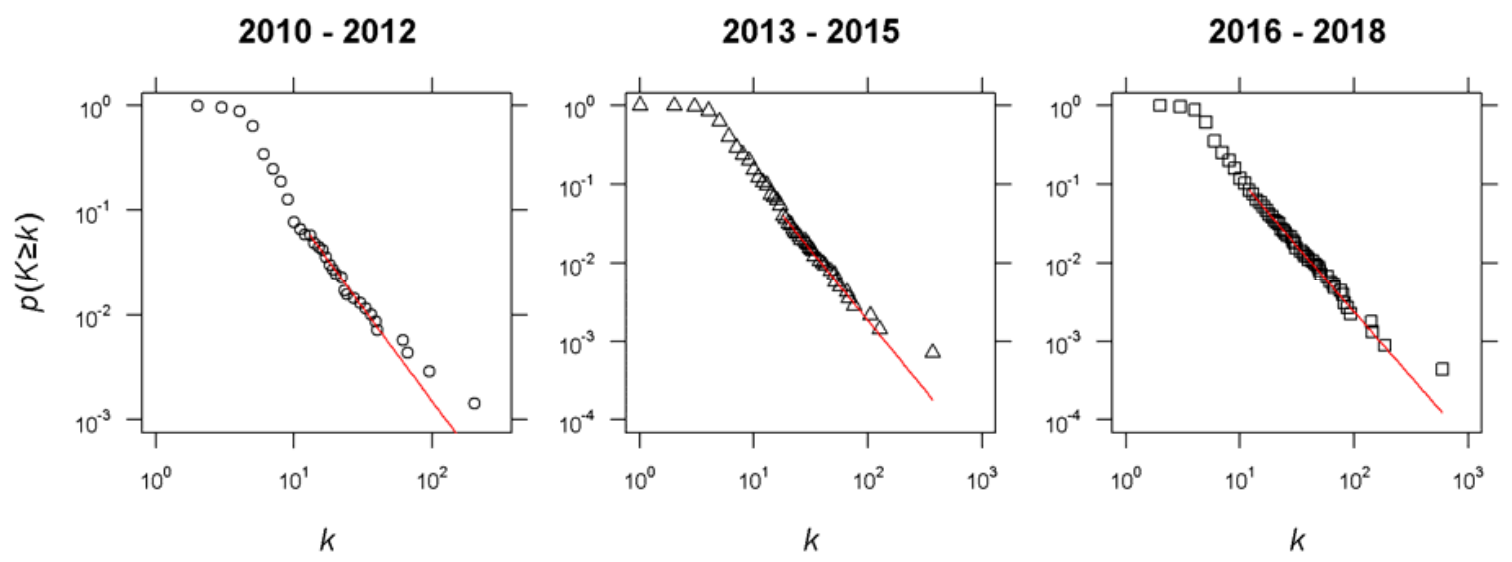

Figure 2. Complementary cumulative distribution function of the keyword co-occurrence networks. The solid line (degree $k$ ) indicates a power law fit, with xmin values 13 for 2010-2012, 18 for 2013-2015, and 12 for 2016-2019, where the power law fit is best.

Table 2 provides a result of the test statistics for 'igraph' and 'poweRlaw' packages in $\mathrm{R}$ over the degree distribution of $\mathrm{KCN}$. The connectivity distribution values were calculated using a degree centrality measure. In the table, the exponent represents the scaling parameter of power-law distributions, the Log likelihood represents the likelihood estimation of the fitted parameters, and the KS statistic represents the distance of the input vector from a fitted distribution [38]. The table presents similar values of both exponent and KS statistics generated by both packages. The highest absolute $\log$-likelihood and $p$-value, and lowest score of KS statistics of 2016-2018 indicates the best fitted to the power-law distribution among the three time periods.

Table 2. Statistical testing measures of power-law fit of the $\mathrm{KCNs}^{\prime}$ distribution for three time periods with R packages 'igraph' and 'poweRlaw'.

\begin{tabular}{ccccccccc}
\hline & \multicolumn{9}{c}{ Igraph } & \multicolumn{3}{c}{ PoweRlaw } \\
\hline & Exponent & xmin & $\begin{array}{c}\text { Log } \\
\text { Likelihood }\end{array}$ & $\begin{array}{c}\text { Kolmogorov-Smirnov } \\
\text { (KS) Statistic }\end{array}$ & $p$-Value & Exponent & xmin & $\begin{array}{c}\text { KS } \\
\text { Statistic }\end{array}$ \\
\hline $2010-2012$ & 2.761695 & 13 & -141.148 & 0.055366 & 0.999694 & 2.762174 & 13 & 0.055780 \\
$2013-2015$ & 2.767996 & 18 & -216.081 & 0.032235 & 0.999999 & 2.768477 & 18 & 0.033375 \\
$2016-2018$ & 2.656433 & 12 & -676.753 & 0.01887 & 0.999999 & 2.65684 & 12 & 0.021028 \\
\hline
\end{tabular}

The five most frequent co-occurring keywords during the period 2010-2012 were "resilience," "climate change," "adaptation," "vulnerability," and "livelihoods" with degrees being 201, 95, 66, 61, and 40, respectively (Table 3). For the years 2013-2015, "resilience," "climate change," "vulnerability," "adaptation," and "livelihoods" were the most frequent co-occurring keywords with degrees of 370, 126, 104, 75, and 67, respectively. For the years 2016-2018, "resilience," "climate change," "adaptation," "vulnerability," and "rural" were the most frequent co-occurring keywords with link degrees of 592, $185,145,141$, and 93 , respectively. 
Table 3. Top fifteen keywords by degree and betweenness.

\begin{tabular}{|c|c|c|c|c|c|c|c|c|}
\hline \multicolumn{3}{|c|}{ Years 2010-2012 } & \multicolumn{3}{|c|}{ Years 2013-2015 } & \multicolumn{3}{|c|}{ Years 2016-2018 } \\
\hline Node & Degree & Betweenness & Node & Degree & Betweenness & Node & Degree & Betweenness \\
\hline Resilience & 201 & 0.4089 & Resilience & 370 & 0.4014 & Resilience & 592 & 0.4270 \\
\hline Climate change & 95 & 0.1407 & Climate change & 126 & 0.1131 & Climate change & 185 & 0.0709 \\
\hline Adaptation & 66 & 0.0617 & Vulnerability & 104 & 0.0472 & Adaptation & 145 & 0.0486 \\
\hline Vulnerability & 61 & 0.0572 & Adaptation & 75 & 0.0365 & Vulnerability & 141 & 0.0453 \\
\hline Livelihoods & 40 & 0.0571 & Livelihoods & 67 & 0.0364 & Rural & 93 & 0.0427 \\
\hline Adaptive capacity & 39 & 0.0408 & Rural & 65 & 0.0321 & China & 87 & 0.0399 \\
\hline Social capital & 36 & 0.0403 & Governance & 57 & 0.0318 & Community resilience & 82 & 0.0355 \\
\hline Rural & 33 & 0.0381 & Gender & 52 & 0.0305 & Sustainability & 80 & 0.0266 \\
\hline Hiv/aids & 30 & 0.0304 & Adaptive capacity & 51 & 0.0302 & Social capital & 80 & 0.0239 \\
\hline Social-ecological systems & 27 & 0.0298 & Food security & 51 & 0.0288 & Adaptive capacity & 76 & 0.0224 \\
\hline Ecosystem services & 24 & 0.0297 & Poverty & 47 & 0.0277 & Food security & 67 & 0.0222 \\
\hline China & 23 & 0.0295 & Flood & 42 & 0.0248 & Livelihoods & 66 & 0.0210 \\
\hline Sub-Saharan Africa & 22 & 0.0266 & Social-ecological resilience & 42 & 0.0235 & Governance & 62 & 0.0202 \\
\hline Drought & 22 & 0.0260 & Community resilience & 40 & 0.0234 & Sustainable development & 58 & 0.0198 \\
\hline Sustainability & 22 & 0.0259 & Sustainability & 38 & 0.0205 & Agriculture & 58 & 0.0167 \\
\hline
\end{tabular}


When looking at disturbance-related or change-related keywords, the most frequent occurring keywords for the period 2010-2012 were "climate change," "Hiv/aids," and "drought," for the period 2013-2015, these were "climate change," "poverty," "food security," and "flood" and for the period 2016-2018, these were "climate change" and "food security." There were also some keywords that constantly appeared in the top fifteen keywords list of all three time periods such as "adaptive capacity" and "sustainability." On the other hand, "community resilience" appeared first in the list of 2013-2015 keywords and became one of the most frequently co-occurring keywords during the period 2016-2018.

The cluster analysis was conducted in order to further examine the networks of a few highly co-occurring keywords such as "resilience," "vulnerability," "adaptation," and "climate change." As a result of the cluster analysis with keywords that appeared more than four times, the number of keywords used for the cluster analysis was 15 keywords for 2010-2012, 32 keywords for 2013-2015, and 69 keywords for 2016-2018. The number of links were 40,135, and 375, respectively. The number of clusters formed for the years 2010-2012 was 5, for 2013-2015 this was 13, and 16 clusters were formed during the period 2016-2018. All clusters were visually drawn in Figure 3, and the list of keywords by total link degree as per three-time windows is summarized in Table 3. In general, Figure 3 shows the expansion of knowledge components and structures through three three-year time periods.

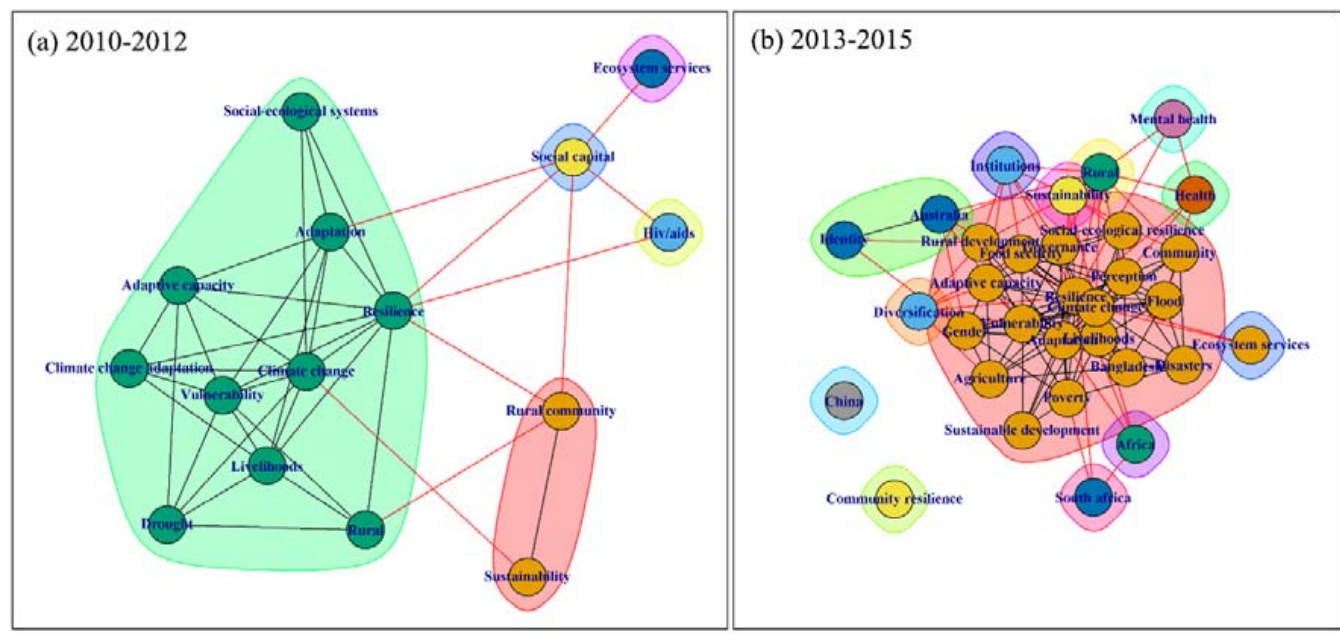

(c) 2016-2018

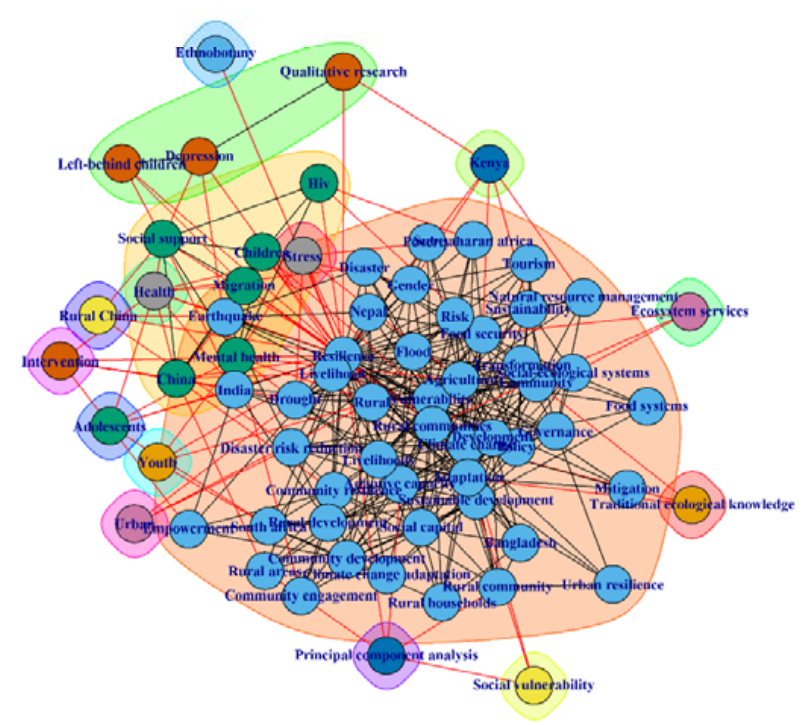

Figure 3. Visualization of KCNs including pairs of keywords that co-occurred 5 times or more for three time windows, with different clusters visualized in different colors (Figures S1-S3 with increased resolution are also provided). 


\subsection{Systematic Review Analysis}

A total of 36 papers were selected with the devised search protocol (see Appendix A). The search results showed that there was a relatively small number of studies with empirical, field-tested evidence for rural resilience assessment or measurement. While we included all studies and contexts related with rural resilience in the $\mathrm{KCN}$ analysis, in the systematic review we excluded psychological and medical related studies and focused on studies relating to social-ecological aspects of rural resilience. The list of selected papers and bibliographic information are provided in Appendix B. We developed a list of eight questions corresponding to our research objective as well as corresponding to the results of the KCN analysis (see Appendix A). The results of these eight questions are summarized in this section.

First, among the shortlisted papers, community resilience (14) and social-ecological resilience frameworks (10) were the most used with few papers using ecological (5) and development resilience frameworks (5) (Figure 4). Geographic and economic aspects were also seen to be relevant to resilience frameworks, particularly in developing countries or regions where development resilience or socioeconomic resilience is important to deal with economic vulnerability. For the definition of rural resilience, many papers used a direct quote of earlier literature, while few researchers attempted to provide operational definitions of rural resilience, often dealing with human dimensions such as the importance of society or community's capacity (Table 4). In general, the notion of resilience referring to the ability or capacity of a system was most frequently used.

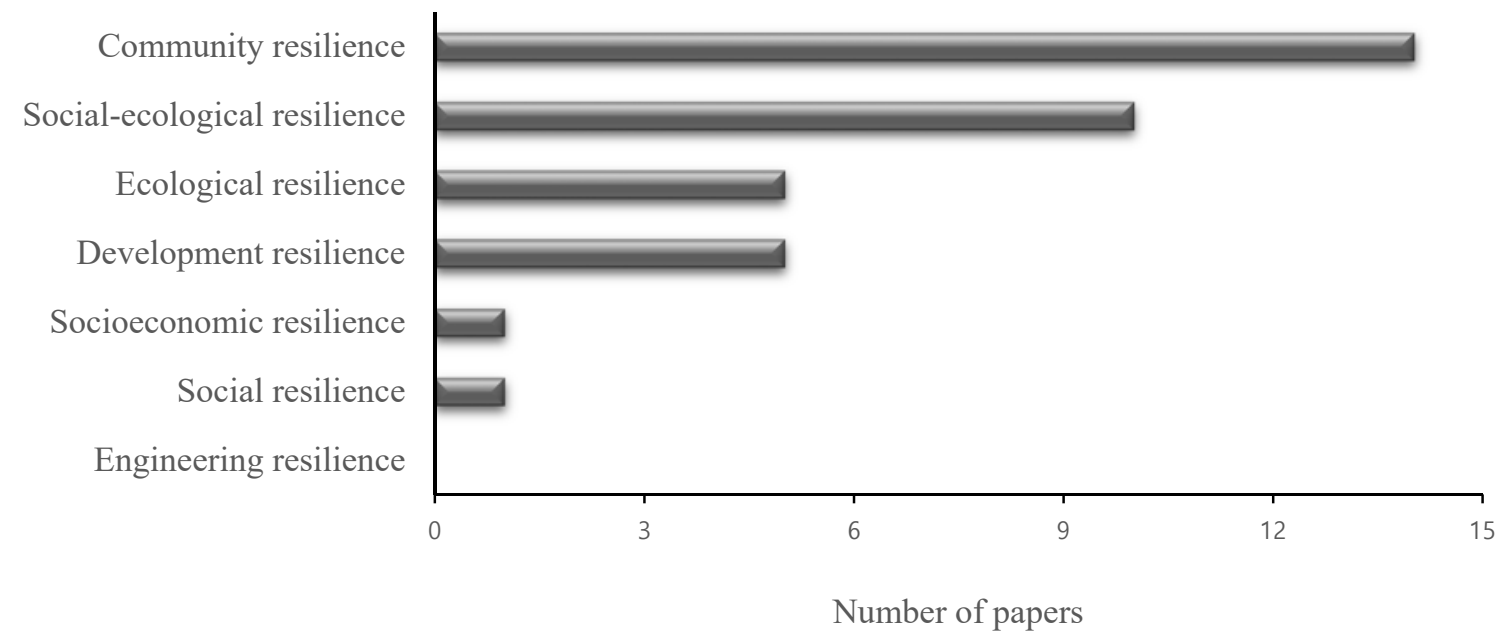

Figure 4. Distribution of resilience frameworks adopted in selected papers for systematic review.

In addition to vulnerability, adaptation, and climate change, and other key concepts used in the papers show a variety of range with examples of livelihood, adaptive capacity, agroecosystem, diversity, diversification, biodiversity, agriculture, learning, and resilience thinking. The papers that contained "vulnerability" as the keyword often listed "household" and "livelihood" as other key concepts. 
Table 4. Notions of rural resilience discussed in the selected papers.

\begin{tabular}{cc} 
Notion of Rural Resilience & Reference \\
\hline $\begin{array}{c}\text { Rural resilience has become popular in recent times, largely as a reaction to the notions of } \\
\text { rural decline. It has become associated with enhancing well-being through having adaptive } \\
\text { behaviors that permit some level of influence over future direction. }\end{array}$ & McManus et al. [39] \\
\hline $\begin{array}{r}\text { Our understanding of resilience includes self-organization, which implies that adaptation } \\
\text { measures are organized by the actors, according to their own needs and visions. }\end{array}$ & Jacobi et al. [40] \\
\hline $\begin{array}{r}\text { Rural community resilience is the source of the outcome, rather than solely the outcome; } \\
\text { contingent on deployment and management of individual, community and/or }\end{array}$ & Skerratt [41] \\
externally-networked stocks of resources and vulnerabilities; cumulatively built through \\
repeated mechanisms and pathways over time or life-course; multi-scale: individual, \\
community, and region; where change is constant not only episodic; not neutral but with \\
The capacity for transformation and adaptation in the face of change.
\end{tabular}

In describing a studied rural system, the rural community was most frequently used in the papers (8), followed by rural households (4), farms (4), rural areas (2), agroecosystems (2), rural villages (2) and farmers (2). Other target systems described in the papers include mountain region, forest and shrub. Moreover, the spatial area for assessing rural resilience was often set at a local scale (31), followed by farm (site) (2) and regional (2) scales.

In terms of disturbance, natural disaster (10), climate change (8), financial crisis and economic changes (5), and land use chances (4) were most often discussed; specific examples of natural disasters included flood (3) and drought (3). Other disturbances included demographic change (2), pest invasion (2), road paving (1), and fertilizer use (1). There were also papers that did not specify disturbance (3).

Almost half of the selected papers employed quantitative methods (17), and 14 papers used qualitative methods. Five papers adopted mixed methods. Many studies, particularly those focused on community resilience, adopted participatory research approaches. Interviews were the most frequently cited participatory approach (7), followed by surveys (5), modeling (5), and GIS (3). The components used in relation to the resilience framework in the selected papers varied and were summarized according to the framework used in the papers, namely ecological, social-ecological, social, development, socio-economic, and community, as in Figure 5. 


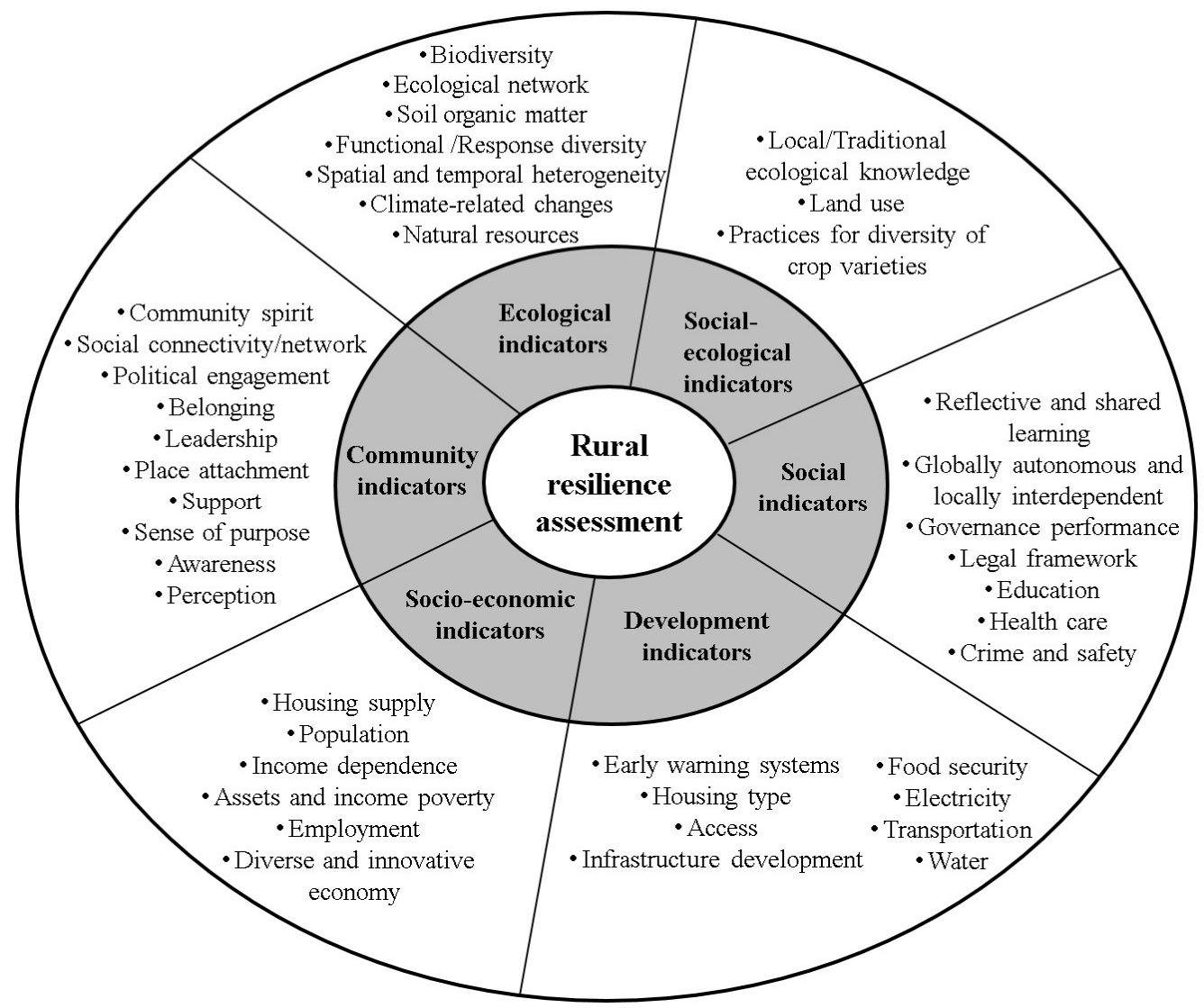

Figure 5. An example of the comprehensive rural resilience indicators observed in systematic review.

\section{Synthesis and Discussion}

The two-step approach to review the rural resilience studies was performed to serve three main objectives: (a) to characterize the state of rural resilience studies by identifying knowledge components, structures, and networks of rural resilience studies; (b) to observe evidence-based tools or indicators of rural resilience that were proposed in the relevant literature; (c) discuss the significance and limitations of rural resilience studies towards addressing the current academic challenges of resilience concept as well as toward enhancing rural sustainability dynamics.

The key findings can be summarized as follows:

1. Both the rate of frequently co-occurring words and the rate of the number of keywords increased, indicating that rural resilience studies have expanded and diversified over the nine examined years.

2. While the knowledge components and structures tend to greatly expand, the high-degree keywords for the three three-year periods remain almost constant with examples of climate change, adaptation, and vulnerability, demonstrating the academic and conceptual characteristics of resilience studies.

3. The KCN shows a scale-free degree distribution, particularly toward the period 2016-2018, indicating characteristics of rural resilience literature, i.e., high-degree keywords playing an important role in the evolution of relevant knowledge.

4. Rural resilience assessment is mostly performed at the local scale, with particular interest in the resilience of rural communities. Overall, community resilience is seen as an interesting component that characterizes the rural resilience studies in 2010s.

5. Climate change, natural disasters, and financial crises are described as the major disturbances for field-tested work, indicating that a globalized process of climate change and economic globalization is prevalent in rural areas worldwide. 
Rural sustainability is inherent to national and global sustainability, and there has been sustained societal interest in assessing and enhancing it. Our result shows that resilience has been gaining increasing interest and importance in rural studies, especially as climate change and economic globalization appear to be accelerated through both global and local processes [44]. The growing interest in rural resilience may imply that rural sustainability dynamics nowadays do not depend on a single factor or event. Rather, there should be the consideration of social, economic, ecological, cultural, and pollical circumstances caused by interdependence in a rural system [23]. The increase in the number of co-occurring keywords represents an enhanced understanding toward complex circumstances and system's interdependence.

On the other hand, our results in association with high degree keywords, such as vulnerability, resilience, and adaptation, and with the systematic review imply the limit and challenges of the current resilience research. It can also be said that rural resilience discourse is tuned with global resilience discourse: the resilience concept tends to remain thematic and academic, generating challenges for researchers to establish measurable proxies and indicators [2]. The strong conceptual relations among vulnerability, resilience, and adaptation may also contribute to such challenges, as researchers may see the need to clarify their conceptual relations. Indeed, vulnerability, resilience, and adaptation were chosen as three key concepts for the International Human Dimensions Programme on Global Environmental Change in 2006 [45]. In global change science, the concepts of adaptation, vulnerability, and resilience are interrelated and applied according to the analytical scale and thematic interest [25].

Having different academic origins, the three knowledge domains of vulnerability, resilience, and adaptation were found to have a weak scholarly network in the late 2000s [46,47]. However, our review of rural resilience shows that they are highly related as important keywords and perform important functions for the evolution of rural resilience literature, indicating that the rural resilience studies incorporate in-depth understandings of the three terms in relation to rural systems. Vulnerability is seen to be associated with a system's sensitivity to disturbance or change [25], and related vulnerability assessments address the lack of social-ecological infrastructure, social capital, and monitoring and management strategies in rural areas [48]. In our systematic review, vulnerability was often found in papers with rural livelihood (resilience) assessments, indicating its distinctive knowledge domain. Moreover, several studies refer to political changes as the primary cause for vulnerability, and use resilience as a pro-active strategy to promote rural community learning, indicating the significance of institutional learning in gaps generated by pursuing social-ecological resilience or community resilience $[11,23,41,49]$. This also indicates that incorporating normative questions within the resilience framework can help to empower minorities and communities to address issues of power and competing value systems that are aspects of rural sustainable development [50].

The knowledge components of rural resilience literature are intimately related to the studied system, system components, methodologies, and elements that enhance resilience. Rural resilience is embedded in the understanding of rural areas as a system, and it evolves conceptually along with the understanding of the system. For example, the term "community resilience" began to appear in rural resilience studies during the period 2013-2015, indicating the evolving conceptualization of resilience with the increasing understanding of human agency and ingenuity in sustainably managing natural resources, developing and communicating ecological knowledge, and devising adaptive strategies to deal with social-ecological changes [51]. The reviewed studies often portray the systems as rural communities and incorporate participatory approaches for engaging community members, indicating that rural resilience studies are focused at the community level and on democratic participation.

In fact, community has been a focus of other rural sustainability frameworks. Sustainable development, for example, was initially proposed as an integrated framework for the analysis of rural systems with a focus on stewardship, self-sufficiency, and community [52]. In the rural resilience literature, the resilience concept was purposefully utilized as a process that enhances the understandings of interactions and dynamics between local communities and the environment. For example, in several studies, rural resilience assessment is employed as a social process to build the adaptive capacity of rural communities, which can foster 
community interests and promote resilience as a means for adaptation and for sustaining socioeconomic development [53]. This also indicates that rural resilience studies provide important alternative frameworks for rural development [54] and challenge the dominant bounce-back resilience framework in favor of a proactive human agency framework [41].

The term agriculture also appeared frequently in recent rural resilience studies, indicating the focus on the ability of rural social-ecological systems to sustain agricultural productivity while maintaining ecological functions and services, in a time of increasing agricultural intensification and technological innovation. Agroecosystems, another keyword with relatively high frequency in the reviewed empirical studies, indicates a growing interest in alternative agricultural management systems that enhance beneficial social and ecological feedbacks and resilience [40]. Rural studies focusing on sustainable agriculture frequently discuss ecosystem services and multi-functionality [55], which is distinct from the dominant industrial agricultural approach of intensive ecological exploitation. Now, it is sufficiently understood that traditional agricultural systems are strongly affected by both global and local processes such as economic globalization, climate change, and political inclusion [56-58].

\section{Conclusions}

Climate change, resilience, vulnerability, adaptation, and management are found to be critical concepts that have shaped the knowledge trend of rural resilience literature in the 2010s, which indicates that rural sustainability dynamics should be embedded in systems concepts highlighting nonlinear changes and interdependencies within a social-ecological system across scales [59,60]. Our systematic review of the rural resilience studies finds that rural resilience assessment is often process-centered and entails systems-oriented learning for enhancing the functioning of ecological or social systems; this indicates a strong focus on resilience thinking. Furthermore, community resilience is found to be an interesting knowledge component that characterizes rural resilience literature toward the end of 2010s. Community resilience in rural contexts indeed possesses great potential for encouraging community-based resource management systems, and is the subject of future research.

There are only few rural resilience assessments, however, these rely on empirical evidence based on field-tested work, and only some studies adopt a clear trans-disciplinary approach. Therefore, a more expanded review of the literature is needed to examine evidence-based rural resilience assessment tools and trans-disciplinary approaches. Despite the limitations of the study, we hope that our efforts in reviewing rural resilience literature contribute to providing more comprehensive analytical lens that combine different framings, concepts, and language, and minimize the chance for miscommunications across different academic disciplines [61].

Supplementary Materials: The following are available online at http://www.mdpi.com/2071-1050/12/22/9769/s1.

Author Contributions: W.K., J.L., and G.K. conceived and designed the analysis, and W.K. and G.K. performed and interpreted the analysis. W.K., J.L., and G.K. wrote the manuscript. All authors have read and agreed to the published version of the manuscript.

Funding: This study was supported by the National Research Foundation of Korea (NRF) grants funded by the government of the Republic of Korea (MSIT): NRF-2018R1A6A3A01012095, No. 2019R1F1A1064166, and NRF-2018R1D1A1B07050805. This paper was also supported by the KU Research Professor Program of Konkuk University.

Conflicts of Interest: The authors declare no conflict of interest. The funders had no role in the design of the study; in the collection, analyses, or interpretation of data; in the writing of the manuscript, or in the decision to publish the results.

\section{Appendix A. Details of Systematic Review}

As stated in our paper, our approach to systematic review is based upon the reviews of studies in biological conservation [35] and adaptive co-management [36]. In addition, since our systematic review is the second phase of the two-step methodology followed by the keyword co-occurrence network $(\mathrm{KCN})$ analysis, we devised a five-state approach to reflect the results of the $\mathrm{KCN}$ analysis as 
well as the overall goal of the review, i.e., to examine how rural resilience analysis and its quantitative and qualitative assessment tools are helping understand the complexity and dynamics of rural social-ecological systems. The five-stage approach includes (1) question formulation, (2) search protocol, (3) the screening of results, (4) analysis, and (5) synthesis of both KCN and systematic review analyses. Details of each stage are explained in this appendix.

Stage One: question formulation. We began from key results from the KCN analysis. The KCN results showed that the most frequent co-occurring keywords throughout the three time periods remained unchanged, with the keywords "resilience," "climate change," "adaptation," "vulnerability," and "management." We found that the terms "resilience," "adaptation," and "vulnerability" have already discussed in previous literature as the concepts that lack clarity or consensus [45]. Based on this finding, we further defined the objective of the review as: (1) to find and characterize the empirical evidence of rural resilience assessment, and (2) to enhance our understanding of "resilience," "adaptation," and "vulnerability" in rural contexts. With the defined objectives, specific questions were formulated as follows: (1) within which resilience framework rural resilience is assessed; (2) how rural resilience is defined; (3) how other key concepts in association with resilience are being defined or clarified, including "vulnerability," "adaptation," and "adaptive capacity"; (4) how a rural (social-ecological) system is framed or defined as a target system; (5) at which scale the resilience concept is applied; (6) what kind of disturbance or change is acknowledge; (7) what components are selected and discussed when assessing rural resilience; and (8) which methods are employed. For the first question regarding the resilience framework, we used engineering resilience, ecological resilience, social-ecological resilience, social resilience, development resilience, socioeconomic resilience, community resilience, and psychological resilience as initial coding themes [21].

Stage Two: search protocol. As the initial search process, among the 1186 papers collected for the $\mathrm{KCN}$ analysis, we searched the ones that have either "assess" or "measure" in their topics or keywords. As a result, 254 papers were shortlisted.

Stage Three: screening of results. The authors of the paper went through the titles, abstracts, and keywords of the 254 papers to find ones that specifically dealt with empirical evidence or field-tested approaches of resilience assessment and contained keywords of "adaptation," "vulnerability," or "adaptive capacity." Then, we imported the shortlisted papers in PDF format into MAXQDA [62], and used the lexical search function of the software to screen the relevance of topic (i.e., whether each study belongs to any resilience framework in the following list: engineering resilience, ecological resilience, social-ecological resilience, social resilience, development resilience, socioeconomic resilience, and community resilience [21]. As stated in the manuscript, papers of psychological resilience were excluded in this process in order to focus on topics relevant to social-ecological systems, natural resource management, or nature-human interactions [36]. As a result of this stage, a total of 36 papers in English are shortlisted as the final list for systematic review.

Stage Four: analysis. A content analysis approach was employed in this stage. The content analysis approach is recommended for qualitative systematic reviewers whose aims are to build knowledge and generate theory [63]. In such a process, highly organizing and contextualizing contents as well as reflective memoing and diagramming are encouraged to ensure the validity of integration, interpretation, and synthesis [63]. While we used the eight questions as coding themes and often used the lexical search function in the MAXQDA program to detect explicitly stated contents, we also conducted open coding to capture all possibilities and potentials [36].

Stage Five: synthesis. To further contextualize the analysis results [63] and synthesize them in relation to the key findings of the $\mathrm{KCN}$ analysis, we further characterized the findings and organized them as key discussion points. 
Appendix B. List of Papers Selected for Systematic Review

\begin{tabular}{|c|c|c|c|}
\hline Author & Title & Publication Year & Journal \\
\hline Robin S. Cox and Marti Hamlen & $\begin{array}{l}\text { Community disaster resilience and the rural } \\
\text { resilience index }\end{array}$ & 2015 & American Behavioral Scientist \\
\hline Phil McManus et al. & $\begin{array}{l}\text { Rural community and rural resilience: what is } \\
\text { important to farmers in keeping their country } \\
\text { towns alive? }\end{array}$ & 2012 & Journal of Rural Studies \\
\hline $\begin{array}{c}\text { Susannah M. Sallu, Chasca Twyman and } \\
\text { Lindsay C. Stringer }\end{array}$ & $\begin{array}{c}\text { Resilient or vulnerable livelihoods? Assessing } \\
\text { livelihood dynamics and trajectories in } \\
\text { rural Botswana }\end{array}$ & 2010 & Ecology and Society \\
\hline Johanna Jacobi et al. & $\begin{array}{l}\text { Agroecosystem resilience and farmers' } \\
\text { perceptions of climate change impacts on cocoa } \\
\text { farms in Alto Beni, Bolivia }\end{array}$ & 2013 & Renewable Agriculture and Food Systems \\
\hline Elizabeth Buikstra et al. & $\begin{array}{l}\text { The components of resilience-perceptions of an } \\
\text { Australian rural community }\end{array}$ & 2010 & Journal of Community Psychology \\
\hline $\begin{array}{c}\text { Mohamed Arouri, Cuong Nguyen and } \\
\text { Adel Ben Youssef }\end{array}$ & $\begin{array}{l}\text { Natural disasters, household welfare, and } \\
\text { resilience: evidence from rural Vietnam }\end{array}$ & 2015 & World Development \\
\hline Sarah Skerratt & $\begin{array}{l}\text { Enhancing the analysis of rural community } \\
\text { resilience: evidence from community land } \\
\text { ownership }\end{array}$ & 2013 & Journal of Rural Studies \\
\hline Jonas Joerin et al. & $\begin{array}{l}\text { Assessing community resilience to climate-related } \\
\text { disasters in Chennai, India }\end{array}$ & 2012 & $\begin{array}{l}\text { International Journal of Disaster } \\
\text { Risk Reduction }\end{array}$ \\
\hline Tim G. Frazier et al. & $\begin{array}{l}\text { Spatial and temporal quantification of resilience at } \\
\text { the community scale }\end{array}$ & 2013 & Applied Geography \\
\hline Corinne Valdivia et al. & $\begin{array}{c}\text { Adapting to climate change in Andean } \\
\text { ecosystems: landscapes, capitals, and perceptions } \\
\text { shaping rural livelihood strategies and linking } \\
\text { knowledge systems }\end{array}$ & 2010 & $\begin{array}{l}\text { Annals of the Association of American } \\
\text { Geographers }\end{array}$ \\
\hline Pablo Tittonell & $\begin{array}{l}\text { Livelihood strategies, resilience and } \\
\text { transformability in African agroecosystems }\end{array}$ & 2014 & Agricultural Systems \\
\hline
\end{tabular}




\begin{tabular}{|c|c|c|c|}
\hline Author & Title & Publication Year & Journal \\
\hline Jeroen C. J. Groot et al. & $\begin{array}{c}\text { Capturing agroecosystem vulnerability and } \\
\text { resilience }\end{array}$ & 2016 & Sustainability \\
\hline Dirk F. van Apeldoorn et al. & $\begin{array}{c}\text { Panarchy rules: rethinking resilience of } \\
\text { agroecosystems, evidence from Dutch } \\
\text { dairy-farming }\end{array}$ & 2011 & Ecology and Society \\
\hline Martín Aluja et al. & $\begin{array}{l}\text { Agroecosystem resilience to an invasive insect } \\
\text { species that could expand its geographical range } \\
\text { in response to global climate change }\end{array}$ & 2014 & Agriculture, Ecosystems and Environment \\
\hline Helena Kahiluoto et al. & $\begin{array}{l}\text { Cultivating resilience by empirically revealing } \\
\text { response diversity }\end{array}$ & 2014 & Global Environmental Change \\
\hline Matt Liebman and Lisa A. Schulte & $\begin{array}{l}\text { Enhancing agroecosystem performance and } \\
\text { resilience through increased diversification of } \\
\text { landscapes and cropping systems }\end{array}$ & 2015 & Elementa: Science of the Anthropocene \\
\hline Ch. Srinivasa Rao et al. & $\begin{array}{l}\text { Agro-ecosystem based sustainability indicators for } \\
\text { climate resilient agriculture in India: a } \\
\text { conceptual framework }\end{array}$ & 2018 & Ecological Indicators \\
\hline Marleen A. H. Schouten et al. & $\begin{array}{c}\text { A resilience-based policy evaluation framework: } \\
\text { application to European rural } \\
\text { development policies }\end{array}$ & 2012 & Ecological Economics \\
\hline Marleen A. H. Schouten et al. & $\begin{array}{l}\text { Resilience-based governance in rural landscapes: } \\
\text { experiments with agri-environment schemes } \\
\text { using a spatially explicit agent-based model }\end{array}$ & 2013 & Land Use Policy \\
\hline $\begin{array}{l}\text { Moseki R. Motsholapheko, Donald L. } \\
\text { Kgathi and Cornelis Vanderpost }\end{array}$ & $\begin{array}{l}\text { Rural livelihoods and household adaptation to } \\
\text { extreme flooding in the Okavango delta, Botswana }\end{array}$ & 2011 & Physics and Chemistry of the Earth \\
\hline Jeff Popke et al. & $\begin{array}{l}\text { A social justice framing of climate change } \\
\text { discourse and policy: adaptation, resilience and } \\
\text { vulnerability in a Jamaican agricultural landscape }\end{array}$ & 2016 & Geoforum \\
\hline Artur Steiner and Marianna Markantoni & $\begin{array}{l}\text { Unpacking community resilience through capacity } \\
\text { for change }\end{array}$ & 2013 & Community Development Journal \\
\hline
\end{tabular}




\begin{tabular}{|c|c|c|c|}
\hline Author & Title & Publication Year & Journal \\
\hline Lin Cassidy and Grenville D. Barnes & $\begin{array}{l}\text { Understanding household connectivity and } \\
\text { resilience in marginal rural communities } \\
\text { through social network analysis in the } \\
\text { village of Habu, Botswana }\end{array}$ & 2012 & Ecology and Society \\
\hline Stephen G. Perz et al. & $\begin{array}{l}\text { Global economic integration and local } \\
\text { community resilience: road paving and rural } \\
\text { demographic change in the southwestern } \\
\text { Amazon }\end{array}$ & 2010 & Rural Sociology \\
\hline Chinwe Ifejika Speranza & $\begin{array}{l}\text { Buffer capacity: capturing a dimension of } \\
\text { resilience to climate change in African } \\
\text { smallholder agriculture }\end{array}$ & 2013 & Regional Environmental Change \\
\hline Aslihan Arslan et al. & $\begin{array}{l}\text { Climate smart agriculture? assessing the } \\
\text { adaptation implications in Zambia }\end{array}$ & 2015 & Journal of Agricultural Economics \\
\hline Helen J. Boon & $\begin{array}{l}\text { Disaster resilience in a flood-impacted rural } \\
\text { Australian town }\end{array}$ & 2014 & Natural Hazards \\
\hline Ana-Isabel García-Arias et al. & $\begin{array}{l}\text { Farm diversification strategies in } \\
\text { northwestern Spain: factors affecting } \\
\text { transitional pathways }\end{array}$ & 2015 & Land Use Policy \\
\hline $\begin{array}{c}\text { Angelo Jonas Imperiale and Frank } \\
\text { Vanclay }\end{array}$ & $\begin{array}{l}\text { Using social impact assessment to strengthen } \\
\text { community resilience in sustainable rural } \\
\text { development in mountain areas }\end{array}$ & 2017 & Mountain Research and Development \\
\hline Claire Kelly et al. & $\begin{array}{c}\text { Community resilience and land degradation } \\
\text { in forest and shrubland socio-ecological } \\
\text { systems: evidence from Gorgoglione, } \\
\text { Basilicata, italy }\end{array}$ & 2015 & Land Use Policy \\
\hline Felipe Murtinho et al. & $\begin{array}{l}\text { Does external funding help adaptation? } \\
\text { evidence from community-based water } \\
\text { management in the Colombian Andes }\end{array}$ & 2013 & Environmental Management \\
\hline
\end{tabular}




\begin{tabular}{|c|c|c|c|}
\hline Author & Title & Publication Year & Journal \\
\hline Quan Nguyen et al. & $\begin{array}{l}\text { Multipurpose agroforestry as a climate } \\
\text { change resiliency option for farmers: an } \\
\text { example of local adaptation in Vietnam }\end{array}$ & 2013 & Climate Change \\
\hline Andrea Pisanelli et al. & $\begin{array}{l}\text { Combining demographic and land-use } \\
\text { dynamics with local communities } \\
\text { perceptions for analyzing socio-ecological } \\
\text { systems: a case study in a mountain area of } \\
\text { Italy }\end{array}$ & 2012 & iForest \\
\hline Alejandro J. Rescia et al. & $\begin{array}{c}\text { Changes in land uses and management in } \\
\text { two nature reserves in Spain: evaluating the } \\
\text { social-ecological resilience of cultural } \\
\text { landscapes }\end{array}$ & 2010 & Landscape and Urban Planning \\
\hline Marleen Schouten et al. & $\begin{array}{l}\text { Resilience-based governance in rural } \\
\text { landscapes: experiments with } \\
\text { agri-environment schemes using a spatially } \\
\text { explicit agent-based model }\end{array}$ & 2013 & Land Use Policy \\
\hline Geoff A. Wilson et al. & $\begin{array}{l}\text { Community resilience in rural China: the } \\
\text { case of Hu village, Sichuan province }\end{array}$ & 2018 & Journal of Rural Studies \\
\hline
\end{tabular}




\section{References}

1. Holling, C.S. Resilience and stability of ecological systems. Annu. Rev. Ecol. Syst. 1973, 4, 1-23. [CrossRef]

2. Schwarz, A.-M.; Béné, C.; Bennett, G.; Boso, D.; Hilly, Z.; Paul, C.; Posala, R.; Sibiti, S.; Andrew, N. Vulnerability and resilience of remote rural communities to shocks and global changes: Empirical analysis from Solomon Islands. Glob. Environ. Chang. 2011, 21, 1128-1140. [CrossRef]

3. Folke, C. Resilience: The emergence of a perspective for social-ecological systems analyses. Glob. Environ. chang. 2006, 16, 253-267. [CrossRef]

4. Anthopoulou, T.; Kaberis, N.; Petrou, M. Aspects and experiences of crisis in rural Greece. Narratives of rural resilience. J. Rural Stud. 2017, 52, 1-11. [CrossRef]

5. Alexander, D.E. Resilience and disaster risk reduction: An etymological journey. Nat. Hazards Earth Syst. Sci. 2013, 13, 2707-2716. [CrossRef]

6. Gentle, P.; Maraseni, T.N. Climate change, poverty and livelihoods: Adaptation practices by rural mountain communities in Nepal. Environ. Sci. Policy 2012, 21, 24-34. [CrossRef]

7. Morton, J.F. The impact of climate change on smallholder and subsistence agriculture. Proc. Natl. Acad. Sci. USA 2007, 104, 19680-19685. [CrossRef]

8. Weichselgartner, J.; Kelman, I. Geographies of resilience: Challenges and opportunities of a descriptive concept. Prog. Hum. Geogr. 2015, 39, 249-267. [CrossRef]

9. Cabell, J.F.; Oelofse, M. An indicator framework for assessing agroecosystem resilience. Ecol. Soc. 2012, 17, 18. [CrossRef]

10. Ramankutty, N.; Mehrabi, Z.; Waha, K.; Jarvis, L.; Kremen, C.; Herrero, M.; Rieseberg, L.H. Trends in global agricultural land use: Implications for environmental health and food security. Annu. Rev. Plant Biol. 2018, 69, 789-815. [CrossRef]

11. Adger, W.N. Social and ecological resilience: Are they related? Prog. Hum. Geogr. 2000, 24, 347-364. [CrossRef]

12. Bebbington, A. Capitals and capabilities: A framework for analyzing peasant viability, rural livelihoods and poverty. World Dev. 1999, 27, 2021-2044. [CrossRef]

13. De Boer, W.F.; Baquete, D.S. Natural resource use, crop damage and attitudes of rural people in the vicinity of the Maputo Elephant Reserve, Mozambique. Environ. Conserv. 1998, 25, 208-218. Available online: https://www.jstor.org/stable/44519444 (accessed on 2 July 2019).

14. Rist, S.; Chidambaranathan, M.; Escobar, C.; Wiesmann, U.; Zimmermann, A. Moving from sustainable management to sustainable governance of natural resources: The role of social learning processes in rural India, Bolivia and Mali. J. Rural Stud. 2007, 23, 23-37. [CrossRef]

15. Shackleton, C.M.; Shackleton, S.E.; Cousins, B. The role of land-based strategies in rural livelihoods: The contribution of arable production, animal husbandry and natural resource harvesting in communal areas in South Africa. Dev. S. Afr. 2001, 18, 581-604. [CrossRef]

16. Collier, M.J.; Nedović-Budić, Z.; Aerts, J.; Connop, S.; Foley, D.; Foley, K.; Newport, D.; McQuaid, S.; Slaev, A.; Verburg, P. Transitioning to resilience and sustainability in urban communities. Cities 2013, 32, S21-S28. [CrossRef]

17. Meerow, S.; Newell, J.P.; Stults, M. Defining urban resilience: A review. Landsc. Urban Plan. 2016, 147, 38-49. [CrossRef]

18. Zhang, X.; Li, H. Urban resilience and urban sustainability: What we know and what do not know? Cities 2018, 72, 141-148. [CrossRef]

19. Ashkenazy, A.; Calvão Chebach, T.; Knickel, K.; Peter, S.; Horowitz, B.; Offenbach, R. Operationalising resilience in farms and rural regions-Findings from fourteen case studies. J. Rural Stud. 2018, 59, $211-221$. [CrossRef]

20. Radhakrishnan, S.; Erbis, S.; Isaacs, J.A.; Kamarthi, S. Novel keyword co-occurrence network-based methods to foster systematic reviews of scientific literature. PLoS ONE 2017, 12, e0172778. [CrossRef]

21. Quinlan, A.E.; Berbés-Blázquez, M.; Haider, L.J.; Peterson, G.D. Measuring and assessing resilience: Broadening understanding through multiple disciplinary perspectives. J. Appl. Ecol. 2016, 53, 677-687. [CrossRef]

22. Carpenter, S.; Walker, B.; Anderies, J.M.; Abel, N.J.E. From metaphor to measurement: Resilience of what to what? Ecosystems 2001, 4, 765-781. [CrossRef] 
23. Wilson, G.A.; Hu, Z.; Rahman, S. Community resilience in rural China: The case of Hu Village, Sichuan Province. J. Rural Stud. 2018, 60, 130-140. [CrossRef]

24. Gallopín, G.C. Linkages between vulnerability, resilience, and adaptive capacity. Glob. Environ. Chang. 2006, 16, 293-303. [CrossRef]

25. Smit, B.; Wandel, J. Adaptation, adaptive capacity and vulnerability. Glob. Environ. Chang. 2006, 16, $282-292$. [CrossRef]

26. Lee, P.-C.; Su, H.-N. Investigating the structure of regional innovation system research through keyword co-occurrence and social network analysis. Innovation 2010, 12, 26-40. [CrossRef]

27. Su, H.-N.; Lee, P.-C. Mapping knowledge structure by keyword co-occurrence: A first look at journal papers in Technology Foresight. Scientometrics 2010, 85, 65-79. [CrossRef]

28. James, D.F.; Tristan, P. What we know, do not know, and need to know about climate change vulnerability in the western Canadian Arctic: A systematic literature review. Environ. Res. Lett. 2010, 5, 014008. Available online: stacks.iop.org/ERL/5/014008 (accessed on 15 August 2019).

29. R Core Team. R: A Language and Environment for Statistical Computing; R Foundation for Statistical Computing: Vienna, Austria, 2018. Available online: http://www.R-project.org/ (accessed on 3 June 2019).

30. Newman, M.E.J. Analysis of weighted networks. Phys. Rev. E 2004, 70, 056131. [CrossRef]

31. Cong, J.; Liu, H. Approaching human language with complex networks. Phys. Life Rev. 2014, 11, 598-618. [CrossRef]

32. Csardi, G.; Nepusz, T. The igraph software package for complex network research. Inter J. Complex Syst. 2006, 1695, 38.

33. Gillespie, C.S. Fitting heavy tailed distributions: The poweRlaw package. J. Stat. Softw. 2015, 64, 1-16.

34. Newman, M.; Girvan, M. Finding and evaluating community structure in networks. Phys. Rev. E 2004, 69, 026113. [CrossRef]

35. Pullin, A.S.; Stewart, G.B. Guidelines for systematic review in conservation and environmental management. Conserv. Biol. 2006, 20, 1647-1656. [CrossRef] [PubMed]

36. Plummer, R.; Crona, B.; Armitage, D.R.; Olsson, P.; Tengö, M.; Yudina, O. Adaptive comanagement: A systematic review and analysis. Ecol. Soc. 2012, 17, 11. [CrossRef]

37. Wuchty, S. Scale-free behavior in protein domain networks. Mol. Biol. Evol. 2001, 18, 1694-1702. [CrossRef]

38. Uddin, S.; Choudhury, N. Actor-level dynamicity: Its distribution analysis eases anomaly detection in longitudinal networks. IEEE Access 2019, 7, 69422-69433. [CrossRef]

39. McManus, P.; Walmsley, J.; Argent, N.; Baum, S.; Bourke, L.; Martin, J.; Pritchard, B.; Sorensen, T. Rural community and rural resilience: What is important to farmers in keeping their country towns alive? J. Rural Stud. 2012, 28, 20-29.

40. Jacobi, J.; Schneider, M.; Bottazzi, P.; Pillco, M.; Calizaya, P.; Rist, S. Agroecosystem resilience and farmers' perceptions of climate change impacts on cocoa farms in Alto Beni, Bolivia. Renew. Agric. Food Syst. 2015, 30, 170-183. [CrossRef]

41. Skerratt, S. Enhancing the analysis of rural community resilience: Evidence from community land ownership. J. Rural Stud. 2013, 31, 36-46. [CrossRef]

42. Rescia, A.J.; Willaarts, B.A.; Schmitz, M.F.; Aguilera, P.A. Changes in land uses and management in two Nature Reserves in Spain: Evaluating the social-ecological resilience of cultural landscapes. Landsc. Urban Plan. 2010, 98, 26-35. [CrossRef]

43. Frazier, T.G.; Thompson, C.M.; Dezzani, R.J.; Butsick, D. Spatial and temporal quantification of resilience at the community scale. Appl. Geogr. 2013, 42, 95-107. [CrossRef]

44. O’Brien, K.L.; Leichenko, R.M. Double exposure: Assessing the impacts of climate change within the context of economic globalization. Glob. Environ. Chang. 2000, 10, 221-232. [CrossRef]

45. Vogel, C. Foreword: Resilience, vulnerability and adaptation: A cross-cutting theme of the International Human Dimensions Programme on Global Environmental Change. Glob. Environ. Chang. 2006, 16, $235-236$. [CrossRef]

46. Janssen, M.A. An update on the scholarly networks on resilience, vulnerability, and adaptation within the Human Dimensions of Global Environmental Change. Ecol. Soc. 2007, 12, 9. [CrossRef]

47. Janssen, M.A.; Schoon, M.L.; Ke, W.; Börner, K. Scholarly networks on resilience, vulnerability and adaptation within the human dimensions of global environmental change. Glob. Environ. Chang. 2006, 16, $240-252$. [CrossRef] 
48. Keogh, D.U.; Apan, A.; Mushtaq, S.; King, D.; Thomas, M. Resilience, vulnerability and adaptive capacity of an inland rural town prone to flooding: A climate change adaptation case study of Charleville, Queensland, Australia. Nat. Hazards 2011, 59, 699-723. [CrossRef]

49. Young, O.R. Institutional dynamics: Resilience, vulnerability and adaptation in environmental and resource regimes. Glob. Environ. Chang. 2010, 20, 378-385. [CrossRef]

50. Cox, R.S.; Hamlen, M. Community disaster resilience and the rural resilience index. Am. Behav. Sci. 2015, 59, 220-237. [CrossRef]

51. Kim, G.; Kang, W.; Lee, D.; Vaswani, R.T.; Chon, J. A spatial approach to climate-resilient infrastructure in coastal social-ecological systems: The case of dumbeong in Goseong County, South Korea. Environ. Int. 2019, 131, 105032. [CrossRef]

52. Smit, B.; Brklacich, M. Sustainable development and the analysis of rural systems. J. Rural Stud. 1989, 5, 405-414. [CrossRef]

53. Folke, C.; Carpenter, S.R.; Walker, B.; Scheffer, M.; Chapin, T.; Rockström, J. Resilience thinking: Integrating resilience, adaptability and transformability. Ecol. Soc. 2010, 15, 20. [CrossRef]

54. Scott, M. Resilience: A Conceptual Lens for Rural Studies? Geogr. Compass 2013, 7, 597-610. [CrossRef]

55. Huang, J.; Tichit, M.; Poulot, M.; Darly, S.; Li, S.; Petit, C.; Aubry, C. Comparative review of multifunctionality and ecosystem services in sustainable agriculture. J. Environ. Manag. 2015, 149, 138-147. [CrossRef]

56. Lebel, L.; Anderies, J.M.; Campbell, B.; Folke, C.; Hatfield-Dodds, S.; Hughes, T.P.; Wilson, J. Governance and the capacity to manage resilience in regional social-ecological systems. Ecol. Soc. 2006, 11, 19. [CrossRef]

57. Shucksmith, M. Class, power and inequality in rural areas: Beyond social exclusion? Soc. Rural. 2012, 52, 377-397. [CrossRef]

58. Yu, D.J.; Anderies, J.M.; Lee, D.; Perez, I. Transformation of resource management institutions under globalization: The case of songgye community forests in South Korea. Ecol. Soc. 2014, 19, 02. [CrossRef]

59. Fischer, J.; Peterson, G.D.; Gardner, T.A.; Gordon, L.J.; Fazey, I.; Elmqvist, T.; Felton, A.; Folke, C.; Dovers, S. Integrating resilience thinking and optimisation for conservation. Trends Ecol. Evol. 2009, 24, 549-554. [CrossRef]

60. Berkes, F. Understanding uncertainty and reducing vulnerability: Lessons from resilience thinking. Nat. Hazards 2007, 41, 283-295. [CrossRef]

61. McEvoy, D.; Fünfgeld, H.; Bosomworth, K. Resilience and climate change adaptation: The importance of framing. Plan. Pract. Res. 2013, 28, 280-293. [CrossRef]

62. VERBI Software. MAXQDA 2018; VERBI Software: Berlin, Germany, 2018. Available online: maxqda.com (accessed on 29 October 2020).

63. Finfgeld-Connett, D. Use of content analysis to conduct knowledge-building and theory-generating qualitative systematic reviews. Qual. Res. 2014, 14, 341-352.

Publisher's Note: MDPI stays neutral with regard to jurisdictional claims in published maps and institutional affiliations.

(C) 2020 by the authors. Licensee MDPI, Basel, Switzerland. This article is an open access article distributed under the terms and conditions of the Creative Commons Attribution (CC BY) license (http://creativecommons.org/licenses/by/4.0/). 